\section{Commentary: Finding the best pulmonary bioprosthetic valve: An unobtainable target?}

\author{
Reilly D. Hobbs, MD, and Ming-Sing Si, MD
}

Pulmonary valve replacement (PVR) has become one of the most common procedures performed in older patients with congenital heart disease. Surgeons and patients can choose from many options for PVR: pulmonary or aortic allograft valves, and stentless or stented porcine or bovine valves. In addition to the various valve types, there are also several manufacturers for each bioprosthetic valve type with differing techniques for fixation, antimineraliztion, and valve design. Even within the category of bioprosthetic valves, there is variability concerning hemodynamic profiles and effective orifice areas. ${ }^{1}$

Most bioprosthetic valves are implanted in the aortic and mitral positions, and thus most of the literature on valve longevity pertains to valves in these positions. In the aortic position, the typical mechanism for bovine pericardial valve failure is that of gradual leaflet calcification and fibrosis leading to gradual valve stenosis, whereas porcine heart valves undergo similar leaflet calcification and fibrosis with the added hazard of more frequent leaflet tearing and valvar insufficiency. The clinical consequence of tears in the bioprosthetic valve leaflets is severe insufficiency and an acutely volume-overloaded heart with the development of heart failure. ${ }^{2,3}$ In the current era, the majority of aortic and mitral valve replacements are with bovine tissue prostheses ${ }^{4}$; however, the evidence for the best choice of valve type is less clear for PVR.

In this issue of the Journal, Kwak and colleagues ${ }^{5}$ examine outcomes at 2 institutions where the porcine (Hancock II, Medtronic, Minn) and the bovine (Carpentier-Edward Perimount, Edwards Lifesciences, Irvine, Calif) bioprosthetic heart valves were implanted in the pulmonic position in patients with

\footnotetext{
From the Section of Pediatric Cardiovascular Surgery, Department of Cardiac Surgery, University of Michigan, Ann Arbor, Mich.

Disclosures: Authors have nothing to disclose with regard to commercial support.

Received for publication Jan 17, 2020; accepted for publication Jan 21, 2020; available ahead of print Feb 7, 2020.

Address for reprints: Ming-Sing Si, MD, 11-735 C.S. Mott Children's Hospital SPC 4204, 1540 E. Hospital Drive, Ann Arbor, MI 48109-4204 (E-mail: mingsing@ umich.edu).

J Thorac Cardiovasc Surg 2020;160:487-8 0022-5223/ $\$ 36.00$

Copyright (c) 2020 Published by Elsevier Inc. on behalf of The American Association for Thoracic Surgery

https://doi.org/10.1016/j.jtcvs.2020.01.054
}

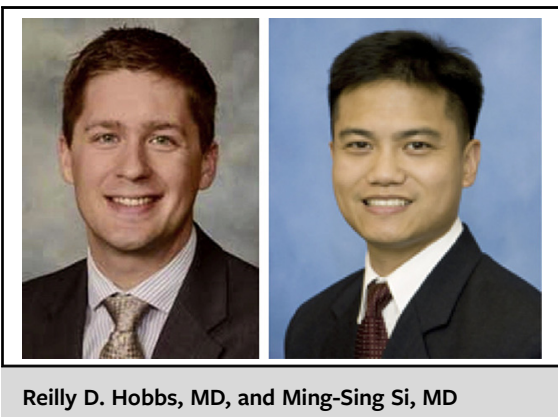

\section{CENTRAL MESSAGE \\ Determining the best pulmonary bioprosthetic valve is difficult, if not impossible.}

congenital heart disease..$^{5}$ These investigators studied 248 patients who had undergone PVR $(n=258$ cases with bioprosthetic valve type distributed equally in both groups) with a median follow-up of 10.5 years and $84.9 \%$ complete follow-up. The authors defined significant valve degeneration as moderate to severe valve regurgitation or a peak velocity of greater than $3.5 \mathrm{~m} / \mathrm{s}$. They observed that patients receiving porcine Hancock II valves were significantly less likely to develop valve degeneration during their study period. Additionally, 64 patients required reoperation for pulmonary valve degeneration. Freedom from reoperation was significantly higher in the porcine Hancock II group. The authors hypothesize that the porcine bioprosthetic valves in the pulmonary valve position are less likely to fracture and more resistant to stenosis than the bovine Carpentier Edwards bioprosthetic valves, which is in contrast to observed outcomes in the aortic and mitral positions. Leaflet fracture was not observed more frequently in patients with elevated pulmonary vascular resistance, suggesting that the observation is not simply due to the pressure phenomena.

Other studies have shown superior outcomes for stented porcine valves in the pulmonary position. A literature review of best evidence articles by Abbas and colleagues ${ }^{6}$ also concluded that stented porcine valves might be superior to bovine valves in the pulmonary position but noted that longer follow-up is needed. Zubairi and colleagues ${ }^{7}$ found that bovine bioprosthetic valves had better, although nonsignificant, actuarial freedom from valve failure at 10 years. ${ }^{7}$ However, the rates of failure were $78 \%$ for bovine valves, $75 \%$ for porcine valves, and $60 \%$ for porcine valves in Dacron conduits $(P=.36)$. Another study by Lee and colleagues, ${ }^{8}$ examining long-term follow-up from 181 implants in patients with congenital heart disease, 
found that stentless porcine valves were significantly less durable than either stented porcine of bovine tissues valves.

Because of the heterogeneity of congenital heart lesions, the differing techniques for valve implant and right ventricular outflow tract reconstruction, the numerous valve types available for PVR, the different manufacturing techniques, and the continued introduction of new bioprosthetic valves into clinical practice, it is difficult-if not impossible-to determine the optimal valve choice in the pulmonary position. Adding to the complexity of the decision of valve choice are new techniques for transcatheter valve-in-valve replacement, and all future PVRs should account for the feasibility of future transcatheter interventions. Kwak and colleagues $^{5}$ have provided valuable clinical insights comparing 2 specific valves in the pulmonary artery position and have demonstrated superior durability in the porcine bioprosthetic valve. Nevertheless, literature offering insights into valve choice is almost entirely retrospective, and this article is no different. There are not enough data to extend their conclusions to other or future bioprosthetic valves. Rigorous scientific studies are needed to determine the best type of xenogenic pericardial material (bovine vs porcine) and if there may be an individualized response to these valves (preformed or acquired antixenogenic antibodies).

\section{References}

1. Pibarot P, Dumesnil JG. Prosthetic heart valves: selection of the optimal prosthesis and long-term management. Circulation. 2009;119:1034-48.

2. Ackers-Johnson M, Li PY, Holmes AP, O’Brien SM, Pavlovic D, Foo RS. A simplified, Langendorff-free method for concomitant isolation of viable cardiac myocytes and nonmyocytes from the adult mouse heart. Circ Res. 2016;119: 909-20.

3. Walley VM, Rubens FD, Campagna M, Pipe AL, Keon WJ. Patterns of failure in Hancock pericardial bioprostheses. J Thorac Cardiovasc Surg. 1991;102:187-94.

4. Yap KH, Murphy R, Devbhandari M, Venkateswaran R. Aortic valve replacement: is porcine or bovine valve better? Interact Cardiovasc Thorac Surg. 2013;16:361-73.

5. Kwak JG, Bang JH, Cho S, Kim ER, Shih BC-H, Lee C-H, et al. Long-term durability of bioprosthetic valves in pulmonary position: pericardial versus porcine valves. J Thorac Cardiovasc Surg. 2020;160:476-84.

6. Abbas JR, Hoschtitzky JA. Which is the best tissue valve used in the pulmonary position, late after previous repair of tetralogy of Fallot? Interact Cardiovasc Thorac Surg. 2013;17:854-60.

7. Zubairi R, Malik S, Jaquiss RD, Imamura M, Gossett J, Morrow WR. Risk factors for prosthesis failure in pulmonary valve replacement. Ann Thorac Surg. 2011;91: $561-5$

8. Lee C, Park CS, Lee CH, Kwak JG, Kim SJ, Shim WS, et al. Durability of bioprosthetic valves in the pulmonary position: long-term follow-up of 181 implants in patients with congenital heart disease. J Thorac Cardiovasc Surg. 2011;142:351-8.
See Article page 476.

\section{Commentary: The conundrum of pulmonary valve substitutes}

\author{
Lucia Cocomello, MD, and \\ Massimo Caputo, MD, FRCS ${ }^{\mathrm{a}, \mathrm{b}}$
}

Bioprosthetic valves have become the preferred option for pulmonary valve replacement in many congenital cardiac centers. ${ }^{1}$ In their report in this issue of the Journal, "Long-Term Durability of Bioprosthetic Valves in Pulmonary Position: Pericardial Versus Porcine Valves," Kwak and collleagues $^{2}$ have retrospectively reviewed their

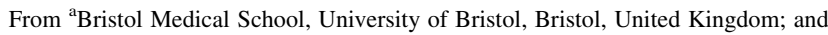
the ${ }^{b}$ Bristol Royal Hospital for Children, University Hospital Bristol NHS Trust, Bristol, United Kingdom.

Disclosures: Authors have nothing to disclose with regard to commercial support.

Received for publication Jan 11, 2020; revisions received Jan 11, 2020; accepted for publication Jan 13, 2020; available ahead of print Jan 31, 2020.

Address for reprints: Massimo Caputo, MD, FRCS, Bristol Heart Institute, Level 7, Bristol Royal Infirmary, BS2 8HW Bristol, United Kingdom (E-mail: m.caputo@ bristol.ac.uk).

J Thorac Cardiovasc Surg 2020;160:488-9

$0022-5223 / \$ 36.00$

Copyright (c) 2020 by The American Association for Thoracic Surgery

https://doi.org/10.1016/j.jtcvs.2020.01.038
Check for updates

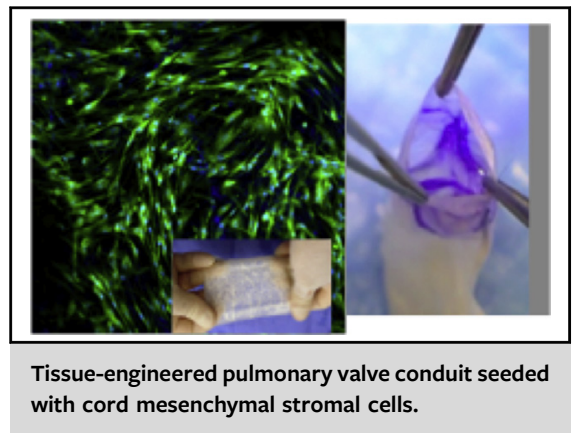

CENTRAL MESSAGE

Considering their significant tissue

degeneration at follow-up, is it time

to reverse the trend toward using

bioprosthetic valves for pulmonary

valve replacement in young pa-

tients for the next decade?

experience with the Hancock II (Medtronic, Minneapolis, Minn) and Carpentier-Edwards Perimount (Edwards Lifesciences, Irvine, Calif) valves in 248 patients from 2 